\title{
DON'T JUdGe A FOOd By ITS LABEL: How A MANDATORY LABELING REQUIREMENT FOR Genetically ENGINEEREd FoOdS Would Generate CONFUSION ABout HeALTH AND FoOd SAFETY AND CREATE ECONOMIC IMPACTS FOR ALL
}

\author{
Chelsea R. Crawford*
}

\section{TABLE OF CONTENTS}

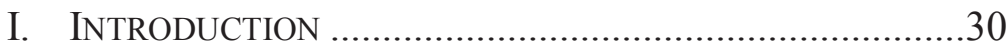

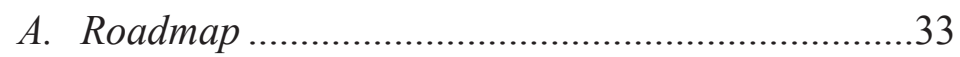

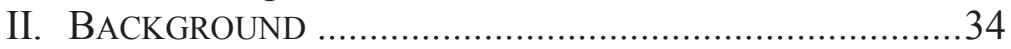

A. What are genetically engineered plants?...............34

B. Evolution in the Regulation of Genetically Engineered Foods ............................................. 36

1. No Federal Statutory Requirements: GE Labeling Not Required .................................36

2. State Legislation..................................................

3. Passage of Federal Mandatory Labeling Law .38

C. The Safe and Accurate Food Labeling Act of 2015

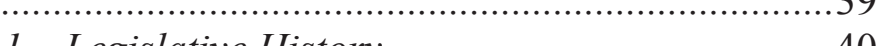

1. Legislative History ......................................40

2. Relevant Sections ...........................................42

III. ANALYSIS .....................................................................44

A. Mandatory Labeling: What are the costs? .............44

B. Costs to Consumers: Confusion.............................46

1. Terminology ....................................................47

2. Health and Food Safety Concerns ..................49

a. "Right to know" ......................................49

b. Brand positioning ......................................52

c. What are "natural" foods? ........................54

1. Primary jurisdiction ............................55

2. Reasonable consumer.........................57

* J.D. Candidate, 2017, Indiana University Robert H. McKinney School of Law; B.A., 2012, Western Illinois University. 
d. Bringing it all together: How the health concerns intersect......................................58

C. Costs to All Americans ..........................................60

1. Vermont's "Right to Know GMOs Act" ..........62

2. Increased Litigation: Constitutional Claims ...62

3. Failures of State Mandatory Genetic Engineering Labeling Laws ..........................66

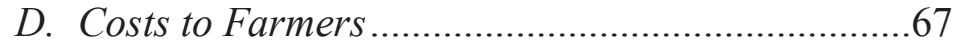

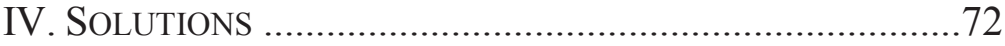

A. Consumer Education..............................................72

1. Genetically Engineered Foods Have Saved

Crops and Humans ........................................73

2. Organic Food as an Alternative ......................75

B. The Safe and Accurate Food Labeling Act of 2015: Revisited ............................................................. 77

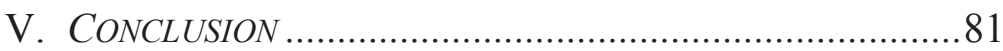

\section{INTRODUCTION}

Millions of acres. Thousands of consumers. Hundreds of countries and states. Three letters. One massive debate. Genetically engineered ("GE") plants, also known as genetically modified organisms ("GMOs"), take center stage in this twenty-year debate over the use of technology in food production. On one side, individuals rely on science to substantiate their claims that genetically engineered plants hold "an impeccable safety record and multiple environmental benefits," 62 and also increase farmers'

62 Examination of the Costs and Impacts of Mandatory Biotechnology Labeling Laws: Hearing Before the H. Comm. on Agric., 114th Cong. 17 (2015) [hereinafter Examination: Hearing] (statement of Nina V. Fedoroff, Ph.D., Senior Science Advisor, Olsson Frank Weeda Terman Matz PC), https://agriculture.house.gov/sites/republicans.agriculture.house.gov/fil es/pdf/114-06\%20-\%2093965.pdf [https://perma.cc/H53D-RY5D]. 
incomes and decrease the prices consumers pay at the store. ${ }^{63}$ But on the other hand, anti-genetic engineering groups assert that growing evidence reveals plants created with biotechnology are harmful to human health and show no benefits to producers or consumers. ${ }^{64}$

With such vastly different perspectives, both seemingly backed by reliable sources, consumer confusion and anxiety concerning genetically engineered foods accelerate to an alltime high. In particular, consumer misunderstandings further perpetuate this debate. Individuals do not fully comprehend biotechnology, or they incorrectly associate the term GMO with negative connotations of unhealthy and dangerous foods. Thus, discerning whether biotechnology is the future or the downfall of America's food supply becomes a difficult task for customers when they are shopping at the grocery store.

The proposed solution? Mandatory labeling, as recently passed into federal law with the National Bioengineered Food Disclosure Standard, also known as S.764 ("S.764"). ${ }^{65}$

${ }^{63} \mathrm{Id}$. at 2 (statement of The Chairman, Hon. K. Michael Conaway, Rep. from Texas).

${ }^{64}$ GMO Facts: Frequently Asked Questions, NON-GMO PROJECT, http://www.nongmoproject.org/learn-more/ [https://perma.cc/E6MAR8QB] (last visited Feb. 24, 2016).

${ }^{65}$ See S.764-A Bill to Reauthorize and Amend the National Sea Grant College Program Act, and for Other Purposes, CONGRESS.Gov, https://www.congress.gov/bill/114th-congress/senate-bill/764

[https://perma.cc/QNU9-QUQ4] (last visited Mar. 27, 2017); see also National Bioengineered Food Disclosure Standard, Pub. L. No. 114-216, $130 \quad$ Stat. 834 (2016), https://www.congress.gov/114/plaws/publ216/PLAW-114publ216.pdf [https://perma.cc/G6QQ-EXR2]; Right to Know Center, JUST LABEL IT, http://www.justlabelit.org/right-to-know-center/

[https://perma.cc/AEF6-X8VM] (last visited Feb. 24, 2016); see also Mandatory Labeling Efforts, NON-GMO PROJECT, http://www.nongmoproject.org/TAKE-ACTION/MANDATORY-

LABELING/ [https://perma.cc/RJQ8-JB68] (last visited Feb. 24, 2016). 
This law implements a mandatory labeling process for all food products containing any genetically engineered ingredients. ${ }^{66}$ The widely known pro-mandatory labeling organization, Just Label It, maintains that mandatory labeling of genetically engineered plants brings a quick resolution to consumer confusion by enabling individuals with the right to know what is in their food and a clear choice of foods made without biotechnology. ${ }^{67}$ Yet, this "easy" solution is not as simple as it appears.

The Lidbacks are first generation farmers raising fifty dairy cows on family land in Westmore, Vermont. ${ }^{68}$ They feed their cattle grain made from genetically engineered corn and soybeans. ${ }^{69}$ However, if the Lidbacks were to alternatively purchase feed produced and labeled as nonGMO, they would need to spend nearly double what they currently pay for feed each year. ${ }^{70}$ In doing so, the family could no longer sustain a profitable business, and their dream of continuing a small dairy farm would cease to exist. ${ }^{71}$ This story is just one example of how the implementation of mandatory labeling could negatively affect the entire chain of food production from farmers to consumers.

The better solution? An established federal framework for voluntary labeling, different from S.764, as set out in The

${ }^{66}$ National Bioengineered Food Disclosure Standard, Pub. L. No. 114-216, $130 \quad$ Stat. $834, \quad 835 \quad \S \quad 293 \quad$ (2016), https://www.congress.gov/114/plaws/pub1216/PLAW-114pub1216.pdf [https://perma.cc/G6QQ-EXR2]; see, e.g., H.B. 112, 2013-2014 Leg. Sess. (Vt. 2014),

http://www.leg.state.vt.us/docs/2014/Acts/ACT120.pdf [https://perma.cc/5N74-99RX].

${ }^{67}$ Right to Know Center, supra note 4.

${ }^{68}$ Examination: Hearing, supra note 1, at 26 (statement of Joanna S. Lidback, Owner, The Farm at Wheeler Mountain).
${ }^{69} \mathrm{Id}$.
${ }^{70} \mathrm{Id}$.
${ }^{71} I d$. 
Safe and Accurate Food Labeling Act of 2015. ${ }^{72}$ This Act creates "a uniform, national system governing the premarket review and labeling of genetically engineered foods." $"$ "73 general terms, the Act will compel the Food and Drug Administration ("FDA") to conduct safety tests on "all new plant varieties" used for genetically engineered foods before they are introduced into the market, and if necessary, demands special labeling for health and safety purposes. ${ }^{74}$ Additionally, the voluntary labeling system would be established for those manufacturers and companies who wish to participate through a United States Department of Agriculture ("USDA") certification process. ${ }^{75}$

The Act would help create consistency in how states regulate and label genetically engineered foods without requiring labels on genetically engineered foods. Mandatory labeling is not a productive solution and will cause additional consumer misperceptions, food safety concerns in the form of "health halos," and financial strain on farmers, manufacturers, and consumers.

\section{A. Roadmap}

This Note addresses these critical issues. Part II focuses on the background of genetically engineered plants, what they are, and where they developed. In addition, this section

72 Safe and Accurate Food Labeling Act of 2015, H.R. 1599, 114th Cong. (2015).

${ }^{73}$ The Safe and Accurate Food Labeling Act of 2015, WEBSITE OF U.S. CONGRESSMAN MIKE POMPEO, http://pompeo.house.gov/uploadedfiles/safla_one_pager_-

114th_congress.pdf [https://perma.cc/D9VF-9GPU] (last visited Feb. 24, 2016) [hereinafter Safe and Accurate Food Labeling Act of 2015 : Pompeo].

${ }^{74}$ Id.; see also Safe and Accurate Food Labeling Act of 2015, H.R. 1599, 114th Cong. § 424(b)(2)(B) (2015).

${ }^{75}$ Safe and Accurate Food Labeling Act of 2015, H.R. 1599, 114th Cong. § 291A (2015). 
discusses the progression of labeling regulations, the recent passage of S.764, its mandatory labeling requirements, and how its voluntary labeling counterpart, the Safe and Accurate Food Labeling Act of 2015, would help generate a better, more established framework for the labeling of genetically engineered foods than S.764. Next, Part III analyzes the costs of mandatory labeling to all American consumers and farmers. Further, this section examines the effects on consumers' viewpoints of health and food safety and the creation of "health halos," or a false sense of healthiness in food labeled as non-genetically engineered. Lastly, Part IV concentrates on how the Act, as well as consumer education, provides solutions for problems that could arise from required mandatory labeling. The Act would help farmers, manufacturers, and consumers more affordably produce and purchase food and prevent a patchwork of state legislation on mandatory labeling, which could make food production difficult.

\section{BACKGROUND}

\section{A. What are genetically engineered plants?}

Genetically engineered plants are produced through the use of biotechnology, ${ }^{76}$ which is "any technological application that uses biological systems, living organisms, or derivatives thereof, to make or modify products or processes for specific use."77 During this process, particular genes

\footnotetext{
${ }^{76}$ Consumer Info About Food From Genetically Engineered Plants, U.S. FOOD AND DRUG ADMIN. (FDA), http://www.fda.gov/Food/FoodScienceResearch/GEPlants/ucm461805. htm [https://perma.cc/N4KV-U6JU] (last updated Oct. 19, 2015).

77 Tadlock Cowan \& Geoffrey S. Becker, Cong. Research SERV., RL32809, AgRiCULTURAL BioteCHNOLOGY: BACKGROUND AND RECENT IsSUES 1 (Feb. 13, 2009) (quoting the Convention of Biological
} 
from an organism are introduced, eliminated, or rearranged through biotechnology, in particular through recombinant deoxyribonucleic acid ("rDNA") methods. ${ }^{78}$

While these definitions adequately describe the science behind genetically engineered plants, the complex terminology and explanations can lead to negative inferences by consumers. In general terms, to produce genetically engineered plants, scientists take desirable genes from one organism (i.e. plants, animals, or microorganisms) and place them into another organism to create plants and animals that have attractive traits, such as being pest or disease resistant. ${ }^{79}$

Genetic engineering focuses on utilizing only these desirable traits. ${ }^{80}$ With traditional plant breeding methods, numerous genes transmit into the plant, which include both advantageous and unwanted traits. ${ }^{81}$ However, through the narrow application of genetic engineering, undesirable characteristics are not transferred to the organism. ${ }^{82}$

Diversity), reprinted in SUSAN A. SCHNEIDER, FOOD, FARMING, AND Sustainability: ReAdings in Agricultural LAW 536 (Carolina Academic Press ed., 2011).

${ }^{78}$ Alison Van Eenennaam et al., COUNCIL FOR AGRIC. SCI. AND TeCH., The Potential Impacts of Mandatory Labeling for Genetically Engineered Food in the United States, Issue Paper 54, 2 (April 2014), http://www.cast-

science.org/download.cfm?PublicationID $=282271 \&$ File=1e30b9edc32 5bd7238e06b551e4a73f4b712TR [https://perma.cc/WK9X-99LZ].

${ }^{79}$ COWAN \& BECKER, supra note 16; see also Frequently Asked Questions on Genetically Modified Foods, WORLD HEALTH ORG. (WHO), http://www.who.int/foodsafety/areas_work/foodtechnology/faq-genetically-modified-food/en/ [https://perma.cc/F36UUKXB] (last visited Mar. 11, 2016).

${ }^{80}$ Consumer Info About Food From Genetically Engineered Plants, supra note 15.

${ }^{81} I d$.

${ }^{82} I d$. 


\section{B. Evolution in the Regulation of Genetically Engineered Foods}

\section{No Federal Statutory Requirements: GE Labeling Not Required}

Prior to July 2016, no clear federal statutory requirements existed for the regulation or mandatory labeling of genetically engineered foods. ${ }^{83}$ The United States followed the Coordinated Framework for Regulation of Biotechnology "to describe the comprehensive federal regulatory policy for ensuring the safety of biotechnology research and products." 84 This framework offers a basis for regulation, which includes these framing principles ${ }^{85}$ : biotechnology shows no unique risks, foods created by biotechnology should be regulated and not the process in which they are made, existing laws are sufficient to regulate genetically engineered foods, and gaps are to be resolved by communication among the various governmental agencies. ${ }^{86}$

Furthermore, under the Coordinated Framework, genetically engineered foods are regulated by the Federal Food, Drug, and Cosmetic Act ("FDCA"), ${ }^{87}$ which requires

${ }^{83}$ Rebecca Bratspies, Some Thoughts on the American Approach to Regulating Genetically Modified Organisms, 16 KAN. J.L. \& PUB. POL'Y 393, 405-417 (2007), reprinted in SUSAN A. SCHNEIDER, FOOD, FARMING, AND SUSTAINABILITY: READINGS IN AgRICULTURAL LAW 541 (Carolina Academic Press ed., 2011) [hereinafter Bratspies]; Peter C. Whitfield, GMO Food Fight: The Latest From the States and Feds, LAW 360, March 28, 2014. In July 2016, new federal law was passed implementing mandatory labeling. See National Bioengineered Food Disclosure Standard, Pub. L. No. 114-216, 130 Stat. 834 (2016), https://www.congress.gov/114/plaws/publ216/PLAW-114publ216.pdf [https://perma.cc/G6QQ-EXR2].

${ }^{84}$ Bratspies, supra note 22, at 541-42.

${ }^{85} \mathrm{Id}$. at 542.

${ }^{86} \mathrm{Id}$.

${ }^{87} \mathrm{Id}$. 
food labels to contain their common or usual name ${ }^{88}$ and reveal all material facts associated with representations or suggestions made on the label itself. ${ }^{89}$ The FDCA grants authority to the FDA to monitor and oversee food safety and labeling of all foods, including those produced by biotechnology. ${ }^{90}$

The FDA depends on science in asserting that foods created through biotechnology do not "present any different or greater safety concern than foods developed by traditional plant breeding," 91 and presumes genetically engineered foods are "generally regarded as safe," or "GRAS," and exempt from labeling within the meaning of the FDCA..$^{92}$ In Alliance for Bio-Integrity v. Shalala, the district court held the FDA's interpretation of the FDCA showed no basis to be considered "arbitrary and capricious." 93 After this court ruling, the FDA reaffirmed its position on biotechnology food labeling in a $2001 \mathrm{draft}$ guidance document, stating that no special labeling requirements are needed for bioengineered foods. ${ }^{94}$

\section{State Legislation}

Although the FDA does not require mandatory labels for genetically engineered foods, many states began to draft and

\footnotetext{
${ }^{88}$ Federal Food, Drug, and Cosmetic Act, 21 U.S.C. § 343(i) (2015); Whitfield, supra note 22.

${ }^{89}$ Federal Food, Drug, and Cosmetic Act, 21 U.S.C § 321(n) (2015); Whitfield, supra note 22.

${ }^{90}$ Bratspies, supra note 22, at 543.

${ }^{91}$ Statement of Policy: Foods Derived from New Plant Varieties, 57 Fed. Reg. 22,984, 22,991 (May 29, 1992).

${ }_{92}$ Bratspies, supra note 22, at 544.

${ }^{93}$ Alliance for Bio-Integrity v. Shalala, 116 F. Supp. 2d 166, 179 (D.D.C. 2000).

${ }^{94}$ Premarket Notice Concerning Bioengineered Foods, 66 Fed. Reg. 4706-01, 4711 (Jan. 18, 2001).
} 
pass laws necessitating labels. As of early 2016, thirty states had approximately seventy bills in the works. ${ }^{95}$ Maine and Connecticut passed separate bills enforcing mandatory labeling, but both acts contained caveats requiring other states to also adopt similar legislation before their laws could be enacted. ${ }^{96}$ Vermont, though, was the first state to require mandatory labeling for genetically engineered foods. ${ }^{97}$ Known as the "Right to Know GMOs" act, the law was scheduled to become effective on July $1,2016 .{ }^{98}$

\section{Passage of Federal Mandatory Labeling Law}

During the editing of this Note, Congress took definitive action in this longstanding GE debate that would affect both state legislation and federal reliance on the Coordinated Framework. On July 31, 2016, President Barack Obama signed S.764 into law, which creates a federal mandatory labeling standard for genetically engineered foods. ${ }^{99}$ This law combines the legislative efforts of Senators Debbie

95 State Labeling Initiatives, CTR. FOR FOOD SAFETY, http://www.centerforfoodsafety.org/issues/976/ge-food-labeling/statelabeling-initiatives\# [https://perma.cc/BFK4-YADA] (last visited Mar. 11, 2016).

${ }^{96}$ Daniel J. Herling et al., Food Fight Over GMOs and the 'Right to Know, 'LAw 360, June 19, 2014; ME. REV. StAT. AnN. tit. 22, § 2596 (2014); CONN. GEN. STAT. ANN. § 21a-92c (West 2015).

${ }^{97}$ Herling et al., supra note 35.

${ }^{98} \mathrm{Id}$.

99 National Bioengineered Food Disclosure Standard, Pub. L. No. 114-216, $\quad 130 \quad$ Stat. $834 \quad$ (2016), https://www.congress.gov/114/plaws/publ216/PLAW-114pub1216.pdf [https://perma.cc/G6QQ-EXR2]; see S.764-A Bill to Reauthorize and Amend the National Sea Grant College Program Act, and for Other Purposes, CONGRESS.Gov, https://www.congress.gov/bill/114thcongress/senate-bill/764 [https://perma.cc/QNU9-QUQ4] (last visited Mar. 27, 2017). 
Stabenow (D-Mich.) and Pat Roberts (R-Kan.) ${ }^{100}$ along with a portion of the Safe and Accurate Food Labeling Act of 2015 , namely its preemption section. ${ }^{101}$ Thus, states, such as Vermont, are now prevented from passing and enforcing labeling laws contradictory to any genetically engineered food labeling standards set forth in this new federal law. ${ }^{102}$ The legislation requires mandatory labeling be disclosed on GE produced foods "through a $\mathrm{QR}$ code, a symbol, 800 [number] or plain text." 103 In addition to these disclosure requirements, S.764 requires the creation of a national mandatory labeling standard by the United States Secretary of Agriculture within two years of the law's passage. ${ }^{104}$

\section{The Safe and Accurate Food Labeling Act of 2015}

Prior to the passage of S.764, the House of Representatives considered a voluntary labeling requirement, the Safe and Accurate Food Labeling Act of

\footnotetext{
${ }^{100}$ See Stephanie Strom, G.M.O. Labeling Bill Clears First Hurdle in Senate, N.Y. TIMES (July 6, 2016), http://www.nytimes.com/2016/07/07/business/gmo-labeling-billpasses-first-hurdle-in-senate.html [https://perma.cc/85DD-23B2].

${ }^{101}$ National Bioengineered Food Disclosure Standard, Pub. L. No. 114-216, $130 \quad$ Stat. $834, \quad 838, \quad \S \quad 295 \quad$ (2016), https://www.congress.gov/114/plaws/publ216/PLAW-114publ216.pdf [https://perma.cc/G6QQ-EXR2]; see Safe and Accurate Food Labeling Act of 2015, H.R. 1599, 114th Cong. § 113 (2015).

${ }^{102}$ See Phil Lempert, Sorry Food Industry, The Historic GMO Food Labeling Bill is Anything But, ForBes (Aug. 1, 2016, 1:24 PM), http://www.forbes.com/sites/phillempert/2016/08/01/sorry-foodindustry-the-historic-gmo-food-labeling-bill-is-anythingbut/\#4ba4408a5e39 [https://perma.cc/W5PF-UD43].

${ }^{103} \mathrm{Id}$.

${ }^{104}$ National Bioengineered Food Disclosure Standard, Pub. L. No. 114-216, $130 \quad$ Stat. $\quad 834, \quad 835, \quad \S \quad 293$ (a) (2016), https://www.congress.gov/114/plaws/publ216/PLAW-114publ216.pdf [https://perma.cc/G6QQ-EXR2].
} 
2015 ("the Act"), which was proposed "[T]o amend the Federal Food, Drug, and Cosmetic Act with respect to food produced from, containing, or consisting of a bioengineered organism, the labeling of natural foods, and for other purposes."105

\section{Legislative History}

The 2015 bill is an amended version of the Safe and Accurate Food Labeling Act of 2014. ${ }^{106}$ The 2014 proposition gave power for voluntary labeling to the FDA and not the USDA, which administers the National Organic program and the Process Verified program. ${ }^{107}$ With the amended 2015 bill, a shift from the FDA to the USDA created a change in jurisdiction from "the House Energy and Commerce Committee, which oversees the FDA, to the House Agriculture Committee, which oversees the USDA."108 This shift to the Agriculture Committee offered "more momentum and provide[d] great assurances of its [the bill's] consideration" in both the House and Senate. ${ }^{109}$ The bill passed in the House of Representatives on July 23, 2015..$^{110}$

In August 2015, the Act moved into the Senate. ${ }^{111}$ Yet, no Democrats offered to lead the issue, which delayed

105 Safe and Accurate Food Labeling Act of 2015, H.R. 1599, 114th Cong. (2015).

${ }^{106}$ Bradley A. McKinney et al., Congress Continues Churning GMO Labeling Legislation, LAW 360, July 31, 2015.

${ }^{107} \mathrm{Id}$.

${ }^{108} I d$.

${ }^{109} I d$.

${ }^{110}$ H.R. 1599- Safe and Accurate Food Labeling Act of 2015, CONGRESS.GOV, https://www.congress.gov/bill/114th-congress/housebill/1599 [https://perma.cc/R7GC-JPF3] (last visited Mar. 11, 2016).

111 Clare Leschin-Hoar, Congress is Having a Messy Food Fight Over GMO Labeling, THE VERGE (Aug. 4, 2015, 12:05 PM), 
introduction. ${ }^{12}$ Additionally, certain actions in the Senate seemed to conflict with the ideas set forth by the Act. In early 2015, the Senate attached an amendment to a spending bill to label genetically engineered salmon. ${ }^{113}$ This amendment, which contradicted the Act by requiring a mandatory label for salmon produced using biotechnology, was passed. ${ }^{114}$

Also, in an October 2015 Senate hearing, ranking member Senator Stabenow stated she was committed to working on a bipartisan genetic engineering labeling "solution," therefore suggesting that the Senate would instead try to endorse its own bill. ${ }^{115}$ In the beginning of 2016, despite pressures to address the Act, the bill remained in the Senate without introduction onto the floor. ${ }^{116}$ Senate Agriculture Committee Group members promised "to make the issue a top priority" as the 2016 sessions began. ${ }^{117}$ However, in March 2016, the Act failed in the Senate mainly because many senators were told not to vote for it. ${ }^{118}$

http://www.theverge.com/2015/8/4/9094579/the-gmo-labeling-debateis-scrambling-partisan-lines [https://perma.cc/G3UW-5XRK].

${ }^{112} I d$.

${ }^{113} \mathrm{Id}$.

${ }^{114} I d$.

115 Jacqui Fatka, Compromise Nearing in 'GMO' Labeling Solution, FARM FUTURES (Oct. 23, 2015), http://farmfutures.com/blogscompromise-nearing-gmo-labeling-solution-10316 [https://perma.cc/53XB-XE5F].

${ }^{116}$ Laura A. Bentele et al., Agriculture, Food, and Health Issues to Watch for 2016, THE NAT'L L. REV. (Jan. 17, 2016), http://www.natlawreview.com/article/agriculture-food-and-healthissues-to-watch-2016 [https://perma.cc/WK77-RJ4Z].

${ }^{117} I d$.

${ }^{118}$ Ken Roseboro, GMO Labeling Efforts Reveal Best and Worst of Democracy, The HufFington Post (July 29, 2016, 5:10 PM), http://www.huffingtonpost.com/ken-roseboro/gmo-labeling-effortsreve_b_11219534.html [https://perma.ccYABZ-E85L] (last updated July 29,2016 ). 


\section{Relevant Sections}

The Act encompasses several sections to aid in generating an organized and helpful system for food labeling, without making it mandatory. First, in creating a federal law regarding labeling of genetically engineered foods, all current and future state laws concerning this type of labeling will be preempted. ${ }^{119}$ This section is one of the few implementations from the Act now required by the new federal mandatory labeling law, S.764. ${ }^{120}$

When a state law is at odds with federal law, the federal law trumps, or preempts, state law and eliminates the state's authority on the issue under the Supremacy Clause of the Constitution. ${ }^{121}$ The Supremacy Clause presents the federal government with a great deal power to enforce preemption. ${ }^{122}$ For example, in the case of genetically engineered foods, the Vermont law is now preempted since

${ }^{119}$ Safe and Accurate Food Labeling Act of 2015, H.R. 1599, 114th Cong. § 113 (2015).

${ }^{120}$ National Bioengineered Food Disclosure Standard, Pub. L. No. 114-216, $130 \quad$ Stat. $834, \quad 835, \quad \S \quad 293$ (a) (2016), https://www.congress.gov/114/plaws/publ216/PLAW-114publ216.pdf [https://perma.cc/G6QQ-EXR2]; see S.764-A Bill to Reauthorize and Amend the National Sea Grant College Program Act, and for Other Purposes, CONGRESS.GOV, https://www.congress.gov/bill/114thcongress/senate-bill/764 [https://perma.cc/QNU9-QUQ4] (last visited Mar. 27, 2017).

121 Preemption, Legal Info. Inst.: CoRnell U. L. SCH., https://law.cornell.edu/wex/preemption [https://perma.cc/N8X2-RD2U] (last visited Mar. 11, 2016); Preemption in Public Health, PUB. Health L. CTR. AT Mitchell Hamline Sch. OF L., http://publichealthlawcenter.org/topics/other-public-healthlaw/preemption-public-health [https://perma.cc/W7MZ-HEKA] (last visited Mar. 11, 2016); U.S. ConST. art. VI, cl. 2.

${ }^{122}$ Preemption in Public Health, supra note 60; U.S. CONST. art. VI, cl. 2 . 
it contradicts the text of the S.764, thus succeeding one of the main goals set forth by the Act. ${ }^{123}$

Second, the Act requires the FDA to take a more active role in the food labeling process. Under the Act, the FDA must conduct safety reviews on all plant varieties used for genetically engineered foods before introduction into the market. ${ }^{124}$ The FDA's authority is still retained to specify special labeling if necessary to protect consumer health and safety. ${ }^{125}$

Additionally, the FDA would be compelled to establish a concrete definition for the term "natural" on food labels. ${ }^{126}$ For years, the agency has declined to further classify or address the definition of "natural." 127 Presently, the use of "natural" is only protested if the foods contain added color, synthetic substances, or artificial flavors. ${ }^{128}$ This lack of clarity has been a catalyst for proponents of mandatory labeling and many class-action lawsuits against companies using the term "natural" on their food labels. ${ }^{129}$

Finally, the legislation establishes a voluntary certification process for those companies who wish to label their products as not containing genetically engineered ingredients. ${ }^{130}$ Companies can submit their products to the USDA, where the products would be sealed with an

${ }^{123}$ Safe and Accurate Food Labeling Act of 2015, H.R. 1599, 114th Cong. § 113 (2015).

${ }^{124}$ Safe and Accurate Food Labeling Act of 2015: Pompeo, supra note 12 .

${ }^{125} \mathrm{Id}$.

${ }^{126}$ Id.; McKinney et al., supra note 45.

${ }^{127}$ McKinney et al., supra note 45.

${ }^{128}$ Allyson Weaver, Note, "Natural" Foods: Inherently Confusing, 39 IOWA J. CORP. L. 657, 663 (2014).

${ }^{129}$ See, e.g., id. at 665.

130 Safe and Accurate Food Labeling Act of 2015: Pompeo, supra note 12 . 
appropriate label. ${ }^{131}$ Under current regulations, products may only be labeled through the Non-GMO Project or through a separate USDA program, which only provides certifications associated with a company's manufacturing process. ${ }^{132}$

While the preemption section of the Act prevailed in the passage of S.764, the new federal law quashed any advancement of the Act's additional sections, such as voluntary labeling, requiring a definition for "natural," and increased action by the FDA. ${ }^{133}$ Therefore, although this federal mandatory labeling law has been passed, it falls short by not addressing the costs associated with mandatory labeling and just offering a temporary solution to the great labeling debate. This Note will continue to address the positives of the Act's voluntary labeling system, explain the undesirability of mandatory labeling, and promote further and future passage of all sections of the Act, including those not addressed by S.764.

III. ANALYSIS

\section{A. Mandatory Labeling: What are the costs?}

The debate over genetically engineered foods covers much more than just a consumer's right to know. A mandatory labeling initiative attacks the process of biotechnology, which generates genetically engineered

${ }^{131}$ McKinney et al., supra note 45.

${ }^{132} \mathrm{Id}$.

${ }^{133}$ National Bioengineered Food Disclosure Standard, Pub. L. No. 114-216, $\quad 130 \quad$ Stat. $\quad 834 \quad$ (2016), https://www.congress.gov/114/plaws/publ216/PLAW-114pub1216.pdf [https://perma.cc/G6QQ-EXR2]; Safe and Accurate Food Labeling Act of 2015, H.R. 1599, 114th Cong. (2015). 
crops. ${ }^{134}$ These crops offer benefits throughout all areas of the food chain. Farmers see higher yields, better incomes to provide for their families, and improved conservation practices, such as using less herbicides, pesticides, and land. ${ }^{135}$ Consumers are able to purchase affordable groceries and retain a plentiful food supply. ${ }^{136}$

However, the proposition of implementing mandatory labeling fails to acknowledge the serious, yet underlying issue associated with labeling: the costs to all, from consumers to manufacturers to farmers. Businesses, on both sides of the issue, have poured millions of dollars into support of their prospective opinions. ${ }^{137}$ Still, aside from the price spent on lobbying, everyone, from consumers to farmers, will see and feel the monetary costs when prices at the supermarkets rise and grain markets fall. ${ }^{138}$

While monetary costs surround a large portion of the debate, intangible costs are also present. These costs include consumer confusion and possible infringement of

${ }^{134}$ William Saletan, Unhealthy Fixation, SLATE (July 15, 2015, 5:45 AM),

http://www.slate.com/articles/health_and_science/science/2015/07/are gmos_safe_yes_the_case_against_them_is_full_of_fraud_lies_and_err ors.html [https://perma.cc/M5QX-AXGW].

${ }^{135}$ Examination: Hearing, supra note 1, at 90 (response of Nina V. Fedoroff, Ph.D., Senior Science Advisor, Olsson Frank Weeda Terman Matz PC).

${ }^{136}$ Id. at 1 (statement of The Chairman, Hon. K. Michael Conaway, Rep. from Texas).

${ }^{137}$ Luke Runyon, Colorado, Oregon Reject GMO Labeling, NAT'L PuB. RADIO (Nov. 5, 2014, 12:39 PM), http://www.npr.org/sections/thesalt/2014/11/05/361750308/coloradosays-no-as-gmo-labeling-continues-to-stumble-at-ballot-box [https://perma.cc/P6CE-9JU5] (last updated Nov. 5, 2014, 1:40 PM).

138 Examination: Hearing, supra note 1, at 2 (statement of The Chairman, Hon. K. Michael Conaway, Rep. from Texas). 
Constitutional rights. ${ }^{139}$ The Act provides a solution for those on both sides of the debate. ${ }^{140}$ Each element of the Act is designed to address the problems mandatory labeling, on a state-by-state basis, could cause to all. ${ }^{141}$ Still, this Act also presents food producers with an opportunity to implement voluntary labeling by the USDA, ${ }^{142}$ which some food companies and restaurant chains favor. ${ }^{143}$

\section{B. Costs to Consumers: Confusion}

In today's world, "the consumer is king," and "[I]t's all about creating a compelling value proposition for the consumer." 144 Products, from smartphones to cars to food, are all marketed toward pleasing the public, who are potential buyers. Consumers appear inundated with opinions given by advocacy groups, celebrities, and the media. Thus, many different misconceptions are presented and developed about genetically engineered crops. From basic terminology questions to health concerns, consumer confusion fuels the fire and keeps it burning in this debate.

139 See John Dillard, Recapping Round 1 of the Vermont GMO-

Labeling Lawsuit, AG WeB (May 4, 2015), http://www.agweb.com/blog/ag-in-the-courtroom/recapping-round-1of-the-vermont-gmo-labeling-lawsuit/ [https://perma.cc/RF84-XFFD].

${ }^{140}$ Safe and Accurate Food Labeling Act of 2015, H.R. 1599, 114th Cong. (2015).

${ }^{141} I d$.

${ }^{142} I d . \S 291 \mathrm{~A}$.

143 See Examination: Hearing, supra note 1, at 34 (statement of Lynn Clarkson, President and Founder, Clarkson Grain Co., Inc.); see also Saletan, supra note 73 (Companies favor voluntary labeling initiatives and have already utilized the voluntary labeling services of the Non-GMO Project to label "more than 27,000 products"). Id.

${ }^{144}$ Jerry Wind et al., The Consumer is King, 9 EuR. Bus. F. 12, 13 (2002). 


\section{Terminology}

Genetically engineered plants and organisms are known by many terms: genetically modified organism, genetically modified ("GM"), transgenic, bioengineered, and the ubiquitous "Frankenfood." 145 This vocabulary tends to create unfavorable and misleading perceptions with consumers. ${ }^{146}$ Since the early 1990 s, the International Food Information Council has found through its research, that the phrase "GMO" is "off-putting" and "frightening" to individuals. ${ }^{147}$ Without any further knowledge, consumers' initial reactions to genetically engineered foods become adverse and worrisome.

Since genetically engineered foods are known by so many varying words, extremely conflicting viewpoints result as to what consumers think about genetically engineered foods. In 2014, the Pew Research Center conducted a study in which $57 \%$ of American citizens believed that it was "unsafe to eat genetically modified foods."148 However, when the International Food Information Council performed a separate study, asking similar questions using "informative language" to explain

145 Van Eenennaam et al., supra note 17, at 2; see Jon Entine, Frankenfood: A Metaphor That Has Cursed GMOs, GENETIC LITERACY PROJECT (Nov. 7, 2014), https://www.geneticliteracyproject.org/2014/11/07/frankenfood-themetaphor-that-has-cursed-gmos/ [https://perma.cc/BCL2-G9ZH].

${ }^{146}$ Examination: Hearing, supra note 1, at 7 (statement of David B. Schmidt, President and Chief Exec. Officer, Int'l Food Info. Council and Found.).

${ }^{147} I d$.

148 Pew Research Ctr., General Public Science Survey 92 (Aug. $15-25$ 2014),

http://www.pewinternet.org/files/2015/01/PI_Science-andsociety_012915.pdf[https://perma.cc/9TQQ-EAHM]. 
the benefits of biotechnology $y^{149}$ as opposed to utilizing the phrase GMOs, the results showed that $67 \%$ of Americans were confident in food safety, and only $2 \%$ stated they were avoiding these products. ${ }^{150}$

The FDA considers genetic engineering "to be the more precise term." 151 Genetically modified organism is inaccurate since genetic engineering actually describes the scientific process used to make the plants and not the actual organism itself. ${ }^{152}$ Also, the phrase does not refer to the exact process of using rDNA since all breeding methods, traditional and bioengineered, result in some type of genetic alteration. ${ }^{153}$ The correct usage of "genetic engineering" and the results of the preceding studies have proven that by using more specific vocabulary, consumers make less biased decisions.

The new federal mandatory labeling law, S.764, also furthers this confusion through its definition of "bioengineering." 154 The FDA stated that the definition of

${ }^{149}$ Examination: Hearing, supra note 1, at 7 (statement of David B. Schmidt, President and Chief Exec. Officer, Int'1 Food Info. Council and Found.).

${ }^{150}$ InT'L Food Info. Council, CONSUMER Perceptions of FoOd

TECHNOlOGY SuRVEY (May 2014),
http://www.foodinsight.org/sites/default/files/FINAL\%20Full\%20Repo rt_IFIC\%202014\%20Food\%20Tech\%20Survey.pdf [https://perma.cc/V2YW-39GW].

${ }^{151}$ Consumer Info About Food From Genetically Engineered Plants, supra note 15.

152 Saletan, supra note 73.

${ }^{153}$ Van Eenennaam et al., supra note 17, at 2.

154 National Bioengineered Food Disclosure Standard, Pub. L. No. 114-216, $130 \quad$ Stat. 834, 834, $\$ \quad 291 \quad$ (2016), https://www.congress.gov/114/plaws/publ216/PLAW-114publ216.pdf [https://perma.cc/G6QQ-EXR2]; see S.764-A Bill to Reauthorize and Amend the National Sea Grant College Program Act, and for Other Purposes, CONGRESS.Gov, https://www.congress.gov/bill/114th- 
"bioengineering" in the law is "narrow" and would "likely mean that many foods from GE sources will not be subject" to coverage under the federal law. ${ }^{155}$ Also, foods from livestock (i.e. meat, milk, or eggs) are not required to have a GE label, "even if the animal ate feed containing GM corn or soybeans." 156 Therefore, the cycle of consumer confusion about precise terminology is not solved through the new federal law, and the purpose of informing consumers about what is in their food is defeated.

\section{Health and Food Safety Concerns}

\section{a. "Right to know"}

Advocates for mandatory labeling of genetically engineered foods claim that consumers deserve the "right to know" what ingredients are in their produce in order to make informed choices about what they eat. ${ }^{157}$ However, those individuals, believing S.764 will provide a federal right to know, are likely to be disappointed by the complex labeling methods provided. Fervent supporters of mandatory labeling, such as Vermont Senator Bernie Sanders, have criticized this new federal law as doing nothing for the

congress/senate-bill/764 [https://perma.cc/QNU9-QUQ4] (last visited Mar. 27, 2017).

155 Fed. Drug Admin. \& Dep'T of Health \& Human Servs., FDA/HHS TeChNicAl Assistance ON SEnAte AgRiculture COMMITTEE DRAFT LEgISLATION TO ESTABLISH A NATIONAL Disclosure STANDARD For BioENGineERED FoOdS (EDW 16734) 2 (June 27, 2016), http://www.centerforfoodsafety.org/files/fda-to-senateag-on-draft-legislation_29928.pdf [https://perma.ccG3D4-RXMM].

156 Aaron M. Phelps, GMO Labeling Bill Signed Into Law, THE

NAT'L LAW REV. (Sept. 25, 2016), http://www.natlawreview.com/article/gmo-labeling-bill-signed-law [https://perma.cc/YA8Z-E85L].

${ }^{157}$ See generally Right to Know Center, supra note 4. 
consumer. ${ }^{158}$ Other mandatory labeling proponents have dubbed this law as the "non-labeling GMO labeling bill.""159 The law requires labeling "through a QR code, a symbol, 800\# number or plain text." 160 Thus, this mandatory labeling does not offer consumers and labeling supporters the information they desire: a clear label stating whether the product was developed by genetic engineering. Additionally, consumers must rely on smartphones to read QR codes or to call or visit websites for more information about the label. ${ }^{161}$ This action provides little help to those consumers wishing to get what Gary Hirshberg of Stonyfield Farm calls "a simple at-a-glance disclosure on the package." 162

However, the push for mandatory labeling of GE foods centers around health concerns. In a 2013 New York Times poll, nearly three-quarters of Americans voiced apprehension about genetically engineered foods believing that they contained ingredients that were harmful to human health. ${ }^{163}$ Some supermarkets and restaurant chains, such as Chipotle, are taking "a cautious approach"164 by eliminating these foods from their facilities. ${ }^{165}$ Additionally, states

\footnotetext{
${ }^{158}$ Roseboro, supra note 57.

${ }^{159} \mathrm{Id}$.

${ }^{160}$ Lempert, supra note 41.

${ }^{161}$ Roseboro, supra note 57; Peggy Lowe, Senators Reach Deal on National GMO Labeling Bill, NAT'L PUB. RADIO (June 23, 2016, 6:39 PM), http://www.npr.org/sections/thesalt/106/06/23/483290269/senateunveils-a-national-gmo-labeling-bill [https://perma.cc/L7W2-GBPM].

${ }^{162}$ Lowe, supra note 100; see generally Roseboro, supra note 57.

${ }^{163}$ Allison Kopicki, Strong Support for Labeling Modified Foods, N.Y. TIMES (July 27, 2013), http://www.nytimes.com/2013/07/28/science/strong-support-forlabeling-modified-foods.html?_r=3\& [https://perma.cc/2EU6-KNWY]. ${ }^{164}$ Saletan, supra note 73.

165 Peggy Lowe, 'GMO-Free' is a Boon for Companies Chasing 'Health Halo' Profits, NAT'L PUB. Radio (Aug. 19, 2015, 4:46 PM), http://www.npr.org/sections/thesalt/2015/08/19/432774389/gmos-are-
} 
continually introduce legislation, such as Vermont's "Right to Know GMOs" Act, to address these "right to know" concerns and require labels for food produced through biotechnology. ${ }^{166}$

Yet, mandatory labeling of genetically engineered foods provides no additional insight as to what the food contains since biotechnology is a method, not an ingredient. ${ }^{167}$ Still, consumers, influenced by the way genetically engineered foods are marketed to them, link those foods and their ingredients to an "unquantifiable health risk, similar to that posed by untested or poorly tested drugs or medication." 168

This misconception generates further consumer confusion through the creation of a health halo effect. Halo effects occur when individuals use one favorable piece of information to reach an overgeneralized conclusion that the focus of that information has more ideal characteristics than it may actually have. ${ }^{169} \mathrm{~A}$ health halo indicates that consumers overestimate the healthfulness of a food based on a narrow characteristic and are influenced more by a label

becoming-a-proxy-for-bigger-concerns-about-the-food-system

[https://perma.cc/EW4M-7TAJ] (last updated Aug. 21, 2015, 2:51 PM).

${ }^{166}$ Herling et al., supra note 35.

167 Kavin Senapathy et al., Scientist and Advocate Moms to Celeb Moms: Weigh GMO Food With Facts Not Fear, Grounded PARENTS (Aug. 19, 2015), http://groundedparents.com/2015/08/19/scientist-andadvocate-moms-to-celeb-on-gmo-food/ [https://perma.cc/Z993-QQGT] (last updated Aug. 23, 2015).

168 Hearing to Consider the Societal Benefits of Biotechnology: Hearing Before the Subcomm. on Horticulture, Research, Biotech., and Foreign Agric. of the H. Comm. on Agric., 113th Cong. 8 (2014) [hereinafter Societal Benefits of Biotechnology: Hearing] (statement of David R. Just, Ph.D., Professor and Co-Dir., Cornell Dyson Sch. of Econ. and Mgmt., Cornell Univ.).

169 Aparna Sundar \& Frank R. Kardes, The Role of Perceived Variability and the Health Halo Effect in Nutritional Inference and Consumption, 32(5) PsYchOL. \& MKTG. 512, 513 (May 2015). 
than the actual nutritional content of the food product. ${ }^{170}$ Health halos have manifested themselves into the biotechnology debate in various ways.

\section{b. Brand positioning}

Restaurants and food producers, which are growing the same food with the same ingredients, see increases in sales after voluntarily labeling their products as non-genetically engineered. These sales rose $30 \%$ and equated to $\$ 1.1$ billion between the summers of 2014 to 2015 , while products with no labels have suffered. ${ }^{171}$

Many businesses voluntarily label genetically engineered food to sell more products and posture their brand as consumer-friendly and not because their merchandise is any healthier than before. This "brand positioning" 172 crafts health halos in the food industry. ${ }^{173}$ Consumers see producers and restaurants actively promoting their "non-GMO" menu items and then compare all other foods in the same category for the same characteristic: ${ }^{174}$ the non-genetically engineered label.

For example, Evolution Salt Company labels their packages as biotechnology free. ${ }^{175}$ Yet, since salt has no genes, labeling is not necessary. ${ }^{176}$ Still, the company's president made the choice to label the salt because their

\footnotetext{
${ }^{170} I d$.

${ }^{171}$ Ilan Brat, Food Goes 'GMO Free' with Same Ingredients, WALL ST. J., Aug. 21, 2015, at B.1.

172 Pierre Chandon \& Brian Wansink, The Biasing Health Halos of Fast-Food Restaurant Health Claims: Lower Calorie Estimates and Higher Side-Dish Consumption Intentions, 34 J. OF CONSUMER RES. 301, 302 (2007).

${ }^{173}$ Lowe, supra note 104.

${ }^{174}$ Chandon \& Wansink, supra note 111.

175 Brat, supra note 110.

${ }^{176} \mathrm{Id}$.
} 
product would be more likely to be purchased over a competitor who did not utilize the non-genetically engineered label. ${ }^{177}$ Likewise, Bentley Mills, owner of BJ's Produce Inc., experienced issues with people questioning whether his greens and herbs were genetically engineered. ${ }^{178}$ While he cultivated the greens in the same manner and without biotechnology, he voluntarily labeled them as nongenetically engineered and saw increased sales and positive customer feedback. ${ }^{179}$

This branding process has fashioned an advertising era in which "you are what you eat" becomes "you are what you think you eat," 180 and consumers can be more easily convinced "that things that weren't good for them were good for them." 181 Marketing tactics aim to use genetically engineering labels to gain an edge on competitors who do not label, even though foods produced through biotechnology have not proven to show adverse effects. ${ }^{182}$ Therefore, although this voluntary labeling process can be useful in giving consumers the "right to know" how their food is made, the promotion of "brand positioning" tells consumers what they want to hear. They want to believe that genetically engineered food is "bad," so producers and

$$
\begin{aligned}
& { }^{177} I d . \\
& { }^{178} I d . \\
& { }^{179} I d .
\end{aligned}
$$

180 Hank Campbell, Do Process Food Labels Help or Harm Consumers? GeNetiC Literacy PROJECT (Jan. 29, 2016), https://www.geneticliteracyproject.org/2016/01/29/process-food-labelshelp-harm-consumers/ [https://perma.cc/4YUL-WWW8].

${ }^{181}$ Lowe, supra note 104.

182 Kent D. Messer et al., Council for Agric. SCI. And Tech, Process Labeling of Food: Consumer Behavior, the Agricultural Sector, and Policy Recommendations, Issue Paper 56, 5, 9 (Oct. 2015), http://www.cast-

science.org/download.cfm?PublicationID=283819\&File=1030ac46417 e576660c87b6b2553352b6624TR [https://perma.cc/7Q3W-Q2WU]. 
manufacturers respond by slapping a non-genetically engineered label on their food products.

\section{c. What are "natural" foods?}

Consumers assume processed foods, labeled as nongenetically engineered, will be healthier and better for them merely because of the label. Low-fat or biotechnology-free food labels, tend to produce positive health halos, which make individuals feel good about purchasing items because it matches their personal values about the food. ${ }^{183}$ For example, a person might feel a non-genetically engineered label means the food is healthier than those derived from biotechnology.

Yet, while anti genetic engineering advocates perpetuate much of this confusion about health, governmental agencies, such as the FDA, have played their part as well. The FDA is in charge of regulating all food labeling, including those foods produced by biotechnology, and ensuring their labels are accurate and not misleading. ${ }^{184}$ However, the food label "natural" leaves much room for dispute as to its true meaning.

In 1993, the FDA issued non-binding guidance refusing to establish a definition for "natural." ${ }^{185}$ Instead, the agency chose to continue using the ambiguous description for "natural" as: "nothing artificial or synthetic (including all

183 Jonathon P. Schuldt, Health Halo Effects of Values-Based Food Claims, 1, 57 (2011) (unpublished Ph.D. dissertation, University of Michigan) (on file with University of Michigan Library), http://deepblue.lib.umich.edu/handle/2027.42/86306 [https://perma.cc/969D-HTHF].

${ }^{184}$ Bratspies, supra note 22, at 543.

185 Food Labeling: Nutrient Content Claims, General Principles, Petitions, Definition of Terms; Definitions of Nutrient Content Claims for the Fat, Fatty Acid, and Cholesterol Content of Food, 58 Fed. Reg. 2303, 2407 (Jan. 6, 1993). 
color additives regardless of source) has been included in, or has been added to, a food that would not normally be expected to be in the food." 186

This lack of clarity surrounding "natural" led to increased litigation due to the general public's uncertainty as to what is a "natural" food. Class action lawsuits claim processed foods, labeled as "all-natural," were found to contain genetically engineered crops. ${ }^{187}$ Courts, though, are split on how to handle the issue of the definition of "natural" and what consumers consider to be healthy versus nonhealthy based on the label. The courts have issued different holdings on two main legal doctrines.

\section{Primary jurisdiction}

On one side, courts employ the primary jurisdiction doctrine. Primary jurisdiction permits courts to stay, or halt, legal proceedings without prejudice to allow an administrative agency to review and resolve a complex issue that falls under their discretion. ${ }^{188}$ To use this doctrine, courts will weigh the following factors:

(1) the need to resolve an issue that (2) has been placed by Congress within the jurisdiction of an administrative body having regulatory authority (3) pursuant to a statute that subjects an industry or activity subjects

${ }^{186} \mathrm{Id}$.

187 See Cox v. Gruma Corp., No. 12-CV-6502 YGR, 2013 WL 3828800 (N.D. Cal. July 11, 2013); see also Barnes v. Campbell Soup, Co., No. C 12-05185 JSW, 2013 WL 5530017, (N.D. Cal. July 25, 2013).

${ }^{188}$ Cox, at *1 (quoting Clark v. Time Warner Cable, 523 F.3d 1110 , 1114 (9th Cir. 2008)). 
an industry or activity to a comprehensive regulatory authority that (4) requires expertise or uniformity in administration. ${ }^{189}$

In Cox v. Gruma Corporation, plaintiffs brought a class action suit alleging that Gruma's food products could not be labeled "all-natural" because they contained genetically engineered corn. ${ }^{190}$ As the government agency in charge of determining whether a label was misleading, ${ }^{191}$ the FDA had previously offered no clarification on the definition of "natural," and the court utilized primary jurisdiction and stayed the case for six months until the FDA could provide any additional explanation. ${ }^{192}$ Similarly, in Barnes $v$. Campbell Soup Company, plaintiffs claimed Campbell's Soup, labeled as "all-natural," contained genetically engineered corn and was mislabeled. ${ }^{193}$ Like Cox, the court held the FDA had authority over this issue and stayed the case until the FDA could shed light. ${ }^{194}$ Nearly six months later, the FDA responded to the courts in both cases, refusing to further define "natural," and the cases were terminated. ${ }^{195}$

${ }^{189}$ Id. (quoting Syntek Semiconductor, Co. v. Microchip Tech., Inc., 307 F.3d 775, 781 (9th Cir. 2002)).

${ }^{190} I d$. at $* 1$.

${ }^{191} \mathrm{Id}$.

${ }^{192} I d$. at $* 2$.

${ }^{193}$ Barnes v. Campbell Soup, Co., No. C 12-05185 JSW, 2013 WL 5530017, at*1 (N.D. Cal. July 25, 2013).

${ }^{194}$ Id. at $* 9$.

${ }^{195}$ See Letter from Leslie Kux, Assistant Comm'r for Policy, Food and Drug Admin., to Hon. Yvonne Gonzalez Rogers, Hon. Jeffrey S. White, \& Hon. Kevin McNulty 1 (Jan. 6, 2014), http://www.foodpolitics.com/wp-content/uploads/Letter-from-FDADeclining-Intervention.pdf [https://perma.cc/RVA7-N6UJ]. 


\section{Reasonable consumer}

Other jurisdictions feel mandatory labeling of genetically engineered foods is not a scientific matter to be delegated to agencies, and courts are "eminently well suited" to decide whether a reasonable consumer was misled by the label. ${ }^{196}$ Courts, such as the Ninth Circuit, state any claim about alleged disingenuous advertising or labeling must be assessed through the reasonable person standard. ${ }^{197}$ Under this standard, the claimant must show that "members of the public are likely to be deceived." 198

Yet, personal beliefs alone about a label's authenticity do not substantiate a claim that a food is "bad" or unhealthy. ${ }^{199}$ In Figy v. Frito-Lay North America, Inc., a class action lawsuit was filed against potato chip magnate, Frito-Lay, Inc., on behalf of California consumers who bought Rold Gold pretzels labeled as "FAT FREE," "LOW FAT," and "Made with All Natural Ingredients." ${ }^{200}$ Plaintiffs asserted that Frito-Lay's labeling practices were misleading since the products actually contained artificial ingredients. ${ }^{201}$ Additionally, the plaintiffs claimed that they cared about what was in their foods and relied on the labels to purchase healthy foods. ${ }^{202}$ The court dismissed the plaintiffs' contentions holding that a bag of pretzels is a commonly

196 In re Frito-Lay North America, Inc. All Natural Litigation, No. 12-MD-2413 (RRM)(RLM), 2013 WL 4647512, at *8 (E.D. N.Y. Aug. 29, 2013) (quoting Jones v. ConAgra Foods, Inc., 912 F. Supp. 2d 889, 898 (N.D. Cal. 2012)).

${ }^{197}$ Freeman v. Time, Inc., 68 F.3d 285, 289 (9th Cir. 1995).

${ }^{198}$ Id. (quoting Bank of the West v. Sup. Ct., 833 P.2d 545, 553 (Cal. 1992)).

199 See Figy v. Frito-Lay North America, Inc., 67 F. Supp. 3d 1075, 1091 (N.D. Cal. 2014).

${ }^{200} \mathrm{Id}$. at $1079-80$.

${ }^{201} \mathrm{Id}$. at 1080 .

${ }^{202}$ Id. 
known processed food, and the claimants offered no reason why the ingredients in the pretzels were not "all natural." 203 The court also rejected allegations that the terms "FAT FREE" and "LOW FAT" were deceptive, and that these terms did not indicate the products were any healthier. ${ }^{204}$

A Minnesota court issued a similar holding in Chin v. General Mills, Inc. ${ }^{205}$ The plaintiffs, who had bought Nature Valley Granola Bars, asserted that the label, "100\% Natural," misinformed individuals because the products were highly processed and led consumers to believe that the products were healthy. ${ }^{206}$ The court rejected the plaintiffs' claims for failing to provide any connection as to how they believed this processed food was any less healthy or offering any additional information concerning what these individuals believed the definition of "natural" entailed. ${ }^{207}$

\section{d. Bringing it all together: How the health concerns intersect}

The cases of Figy and Chin show a strong intersection of where consumer confusion, brand positioning, health halos, and the reasonable consumer standard all meet. Companies position their brand and begin labeling in order to continue making a profit and also to edge out competitors ${ }^{208}$ although they still use genetically engineered ingredients, and this action can cause consumers to possibly base food choices on a false sense of healthiness and create a health halo. ${ }^{209}$

${ }^{203}$ Id. at 1090 .

${ }^{204} \mathrm{Id}$. at 1091.

${ }^{205}$ Chin v. General Mills, Inc., No. 12-2150 (MJD/TNL), 2013 WL 2420455, at*9 (D. Minn. June 3, 2013).

206 Id. at $* 2, * 8$.

${ }^{207} I d$. at $* 9$.

${ }^{208}$ See, e.g., Brat, supra note 110; Messer et al., supra note 121, at 5.

${ }^{209}$ Sundar \& Kardes, supra note 108. 
Then, consumers may realize that these products, although labeled appropriately, do not meet their personal standards for health, and they likely cannot bring successful legal claims because, as seen in these preceding cases, a values-based belief is not substantial proof to corroborate a legal claim against a manufacturer. ${ }^{210}$ This rationalization applies to how genetically engineered foods could be viewed with a requirement of mandatory labeling. Individuals might regard processed foods, labeled "GMO-free," as healthier or more desirable when in fact they may be no more nutritious than their genetically engineered counterpart and vice versa. Furthermore, brand positioning can still generate doubt that lingers in the minds of consumers as to what constitutes "natural" foods and whether or not these foods meet their view of healthiness, and the vicious cycle of consumer confusion keeps turning.

On the other hand, reasonable consumer claims, challenging "all natural" labels, could be valid because the FDA has taken no action to further define "natural" and factor in how genetically engineered foods fit into the equation. Courts have held in favor of plaintiffs and considered them to be reasonable consumers because of the FDA's failure to act. ${ }^{211}$ In Jones v. ConAgra Foods, the court found that the FDA's inactivity implied that the agency does not see a need for "uniformity in administration," and without further action, the court will not defer to the FDA. ${ }^{212}$

Mandatory labeling will not solve the problems of a consumer's right to know. Instead, this action will create further problems and misunderstandings about genetically engineered foods and their health value. But, regardless of which side of the genetically engineered debate a person

${ }^{210}$ See Figy v. Frito-Lay North America, Inc., 67 F. Supp. 3d 1075, 1091 (N.D. Cal. 2014); see Chin, 2013 WL 2420455, at *9.

211 See Jones v. ConAgra Foods, Inc., 912 F. Supp. 2d 889, 899 (N.D. Cal. 2012).

${ }^{212}$ Id. at 898 . 
falls on, the FDA needs to define "natural" to establish some national uniformity and greatly decrease the public's misunderstandings of biotechnology. Since genetically engineered foods are no different in their end result than their traditionally produced counterparts, they should be included in the definition of "natural."

\section{Costs to All Americans}

Although S.764 now preempts states from passing any legislation contrary to the federal laws on the labeling of genetically engineered foods, ${ }^{213}$ this section offers an explanation of the United States' framework prior to the law's passage and the negative implications that framework set forth.

State-by-state laws for the mandatory labeling of genetically engineered foods create a "patchwork" of laws with different standards, definitions, and exemptions. ${ }^{214}$ Essentially, each state may have its own food labeling law resulting in a possibility of fifty different laws in the entire country. This action generates an "activist minority" problem, where a small number of states enacting labeling legislation could control biotechnology labeling of all states. ${ }^{215}$ Therefore, individual state labeling laws might be

213 National Bioengineered Food Disclosure Standard, Pub. L. No.

114-216, $130 \quad$ Stat. 834, 838, \$295(b) (2016), https://www.congress.gov/114/plaws/publ216/PLAW-114publ216.pdf [https://perma.cc/G6QQ-EXR2]; see S.764-A Bill to Reauthorize and Amend the National Sea Grant College Program Act, and for Other Purposes, CONGRESS.Gov, https://www.congress.gov/bill/114thcongress/senate-bill/764 [https://perma.cc/QNU9-QUQ4] (last visited Mar. 27, 2017).

${ }^{214}$ Examination: Hearing, supra note 1, at 42 (statement of Chris Policinski, President and Chief Exec. Officer of Land 'O Lakes, Inc.).

${ }^{215}$ Herling et al., supra note 35. 
difficult to navigate and costly on each level of the production and consumption chain. ${ }^{216}$

Manufacturers of food products would take an extremely hard hit at every step of their distribution process. These businesses could find increased costs to produce and see a required rise in inventory, difficulty packaging and distributing in order to observe each state's labeling laws, and "extensive new regulatory and training requirements." 217 With differing labeling laws, manufacturers may only have three ways to comply: "redesign their packaging, reformulate products so that no labeling is required, or halt sales to that state." 218 Additionally, these options develop massive problems that are "time-intensive" and could even cut jobs from the manufacturers' businesses. ${ }^{219}$

Further, consumers, the ultimate target of all food products, face higher prices at supermarkets if individual state mandatory labeling laws go into effect. ${ }^{220}$ Due to the complexities and extra time needed by manufacturers to comply with each state's laws, some food products might not be readily available, and consumers will lose their choice in purchasing products they want when they want them. ${ }^{221}$ While Vermont is one of the few states that passed a law requiring mandatory labeling, ${ }^{222}$ the bill demonstrates a prime example of how a state's biotechnology labeling law

216 Id.

${ }^{217}$ Examination: Hearing, supra note 1, at 35 (statement of Thomas W. Dempsey, Jr., President and Chief Exec. Officer, Snack Food Association).

${ }^{218}$ Id.

${ }^{219} I d$.

${ }^{220} I d$. at 36.

${ }^{221} I d$.

222 H.B. 112, 2013-2014 Leg. Sess. (Vt. 2014), http://www.leg.state.vt.us/docs/2014/Acts/ACT120.pdf [https://perma.cc/5N74-99RX]. 
can cause negative effects, perceptions, and increased litigation.

\section{Vermont's "Right to Know GMOs Act"}

Vermont's "Right to Know GMOs" Act ("Act 120") necessitates labels stating the food "may be partially produced with genetic engineering." 223 Act 120 describes how genetically engineered plants "may" or "potentially" pose "unintended consequences." 224 For a bill that maintains to "simply require" 225 labeling of foods produced with genetic engineering, it essentially creates more unnecessary fear and worry for consumers. Additionally, Act 120 harbors a contradictory exemptions section. ${ }^{226}$ For example, processed foods, including processing enzymes made from genetic engineering, are not subject to labeling requirements. ${ }^{227}$ Act 120 should not have exemptions for any foods containing any level or amount of genetically engineered enzymes. Therefore, the conflicting messages of Act 120 present another example of consumer misunderstandings created by unfavorable and incorrect use of language.

\section{Increased Litigation: Constitutional Claims}

Consumer confusion is not the only issue developing out of the passage of Act 120, and litigation quickly followed. In

${ }^{223}$ Herling et al., supra note 35 .

224 H.B. 112, 2013-2014 Leg. Sess. $§ 1$ (Vt. 2014) http://www.leg.state.vt.us/docs/2014/Acts/ACT120.pdf [https://perma.cc/5N74-99RX]..

${ }^{225}$ FAQs, Where Would the Labels Be?, VERMONT Right TO KNOW GMOs, http://www.vtrighttoknowgmos.org/faq/ [https://perma.cc/238X-D8JF] (last visited Feb. 26, 2015).

${ }^{226}$ H.B. 112, 2013-2014 Leg. Sess. § 3044 (Vt. 2014).

${ }^{227} \mathrm{Id}$. 
Grocery Manufacturers Association v. Sorrell, the Grocery Manufacturers Association challenged Act 120 claiming it violated the Constitution under the Commerce Clause, Supremacy Clause, and First Amendment. ${ }^{228}$ While this Note focuses primarily on the Commerce Clause challenge, Sorrell indicated a tendency for further increased litigation following the establishment of other individual state laws.

The Commerce Clause gives Congress power "[T]o regulate Commerce with foreign Nations, and among the several States, and with the Indian Tribes."229 Within the Commerce Clause, the implied "dormant" Commerce Clause prevents states from passing any law that "discriminates against or excessively burdens interstate commerce." 230 In Sorrell, the Grocery Manufacturers Association claims Act 120 infringed the Commerce Clause, and the mandatory labeling law created "an undue burden on interstate commerce, ultimately resulting in a 50-state patchwork of labeling laws." 231 Still, the United States District Court for the District of Vermont dismissed the claim to the extent that labeling was unconstitutional under the Commerce Clause and because no other states had conflicting labeling laws. ${ }^{232}$

While the District Court's holding is correct, this ruling could easily change if even one other state passes a mandatory labeling law for genetically engineered foods that is inconsistent to Vermont's legislation. A great example of the potential ramifications of contradictory labeling laws

${ }^{228}$ Dillard, supra note 78.

${ }^{229}$ U.S. CONST. art. $1, \S 8$, cl. 3.

${ }^{230}$ Commerce Clause, Legal Info. Inst.: CORnell U. SCH. OF L., https://www.law.cornell.edu/wex/commerce_clause [https://perma.cc/MJC8-L3HT] (last visited Feb. 26, 2016).

${ }^{231}$ Dillard, supra note 78.

${ }^{232} I d$. 
played out in the United States Supreme Court case Hunt v. Washington State Apple Advertising Commission. ${ }^{233}$

In Hunt, North Carolina adopted a statute requiring all closed containers of apples shipped into the state to display "either the applicable USDA grade or none at all." 234 Washington State, the United States' largest producer of apples, labeled all of its apples with its own state grade. ${ }^{235}$ Due to its strict inspection standards, Washington's grades garnered extensive acceptance and were considered equal or more superior to the USDA grades. ${ }^{236}$ Since Washington sent apples all over the country with these grades, the state had to change their shipping methods specifically for North Carolina alone, which was incredibly expensive (approximately $\$ 1$ million each year). ${ }^{237}$ Washington apple growers challenged the North Carolina statute as an unreasonable burden on interstate commerce by forcing them to prove their apples were better quality, which is a discriminatory motive. ${ }^{238}$

North Carolina claimed the USDA label was used so consumers could know what they were getting, which is facially non-discriminatory. ${ }^{239}$ The Supreme Court held that although facially neutral, the North Carolina statute burdened interstate sales of Washington apples and was discriminatory. ${ }^{240}$ This statute raised the cost of doing business in Washington, while costs for North Carolina growers were unaffected. ${ }^{241}$

${ }^{233}$ Hunt v. Wash. State Apple Adver. Comm'n, 432 U.S. 333 (1977).

${ }^{234} \mathrm{Id}$. at 337.

${ }^{235} \mathrm{Id}$. at $336-38$.

${ }^{236} \mathrm{Id}$. at 336 .

${ }^{237} \mathrm{Id}$. at $336,338$.

${ }^{238}$ Id. at $334,349$.

${ }^{239} \mathrm{Id}$. at 349 .

${ }^{240} \mathrm{Id}$. at $350-52$.

${ }^{241} \mathrm{Id}$. at 351 . 
Hunt shows how two states' different labeling requirements can cause problems for food distributors throughout the country. North Carolina claimed to be using the USDA label because consumers have the right to know the specific quality of their apples. ${ }^{242}$ Similarly, Vermont is also claiming that their citizens have a right to know if genetic engineering was used in producing their food and should be labeled as such. ${ }^{243}$ Therefore, like North Carolina's statute, Act 120 had the potential to burden interstate sales of genetically engineered foods into Vermont and raised manufacturers' costs of doing business in the state of Vermont only.

If other states passed mandatory labeling laws, the problems that the Washington state growers had in Hunt would surface. Unlike Washington's apple grades, individual state laws are not the accepted industry standards for labeling of genetically engineered foods and are not superior to any USDA voluntary labeling, which is provided by the Safe and Affordable Food Labeling Act of 2015. Therefore, if Act 120 or other state labeling laws would take effect, manufacturers would have to change their packaging and distribution methods based on each individual state's labeling requirements and not the industry standard, or they would be forced to stop shipping to those states altogether. Thus, manufacturers and distributors face costs of different labeling and shipping; farmers face costs to their income; and consumers face costs at the supermarkets or are required to find other places to purchase certain foods.

Sorrell provided further verification that state-by-state mandatory labeling, could cause increased litigation and potential for infringement on Constitutional rights of individuals. If more state mandatory labeling laws were

\footnotetext{
${ }^{242} I d$. at 349.

${ }^{243}$ H.B. 112, 2013-2014 Leg. Sess. § 1 (Vt. 2014).
} 
passed, the potential for burdens on interstate commerce and Commerce Clause violations would continue to grow.

\section{Failures of State Mandatory Genetic Engineering Labeling Laws}

Although Vermont was successful in its endeavors to pass Act 120, most mandatory labeling laws failed at state levels. As of 2014, seven citizen-lead and legislative initiatives for mandatory labeling of genetically engineered foods did not pass. ${ }^{244}$ In early 2015 , Indiana introduced three separate bills to require labeling for genetically engineered foods sold within the state. ${ }^{245}$ However, the bills did not receive a hearing or a vote. ${ }^{246}$ Because Indiana is a largely agricultural state, the failure of a bill which could potentially have an adverse effect on farmers comes as no surprise.

Additionally, in 2014, both Oregon's and Colorado's labeling measures failed. Colorado's Proposition 105, which would have required food manufacturers to label genetically engineered foods as "produced with genetic engineering," lost with a significant majority of individuals (66\%) voting against the measure. ${ }^{247}$ Oregon saw a slim victory over antibiotechnology opponents with less than $51 \%$ of citizens voting against Measure 92. ${ }^{248}$

In both instances, companies from both sides of the debate invested millions of dollars to advocate for their

244 Carmen Bain \& Tamera Dandachi, Governing GMOs: The (Counter) Movement for Mandatory and Voluntary Non-GMO Labels, 6(12) SUSTAINABILITY 9456, 9463 (2014), http://www.mdpi.com/20711050/6/12/9456/htm [https://perma.cc/CAM6-4M56] (see Figure 1. 2014 GMO Legislation Tracking Map).

245 Patrick Pfingsten, 2015 Indiana Legislative Session Important for Indiana Farmers, IND. CORN \& SOYBEAN REV., Summer 2015, at 10.

${ }^{246} I d$.

${ }^{247}$ Runyon, supra note 76.

${ }^{248} I d$. 
respective viewpoint. In Oregon, approximately \$28 million was spent, and \$13 million was devoted to the cause in Colorado. ${ }^{249}$ Food companies, such as Nestle, Kraft Foods, and Coca-Cola, joined together to fund the campaigns against these bills. ${ }^{250}$ While these companies have a financial advantage, they spent the money to help businesses keep producing without added costs to all involved in the food chain and to prevent further consumer confusion. Chad Vorthmann, executive vice president of the Colorado Farm Bureau, confirms this assertion: "[t]he reality is, campaigns cost money, and I'm really proud to say that groups like Smucker's, like Pepsi, stood shoulder to shoulder with the farmers that are growing their ingredients. $" 251$

However, all of the costs spent on both sides of this issue could have been averted and appropriated toward other, beneficial uses if a national standard, such as the preemption section of S.764, ${ }^{252}$ was in place at that time to stop states from passing individual mandatory labeling laws.

\section{Costs to Farmers}

The genetic engineering debate tends to primarily focus on the consumer: their "right to know," their right to choose certain foods, and their concerns about health. ${ }^{253}$ Yet, many

\footnotetext{
${ }^{249}$ Bain \& Dandachi, supra note 183, at 9465 (see Table 1.).

${ }^{250} \mathrm{Id}$. at 9464 .

${ }^{251}$ Runyon, supra note 76.

${ }^{252}$ National Bioengineered Food Disclosure Standard, Pub. L. No. 114-216, $130 \quad$ Stat. $834, \quad 838, \quad \S 295(\mathrm{~b}) \quad$ (2016), https://www.congress.gov/114/plaws/pub1216/PLAW-114publ216.pdf [https://perma.cc/G6QQ-EXR2]; see S.764-A Bill to Reauthorize and Amend the National Sea Grant College Program Act, and for Other Purposes, CONGRESS.GOV, https://www.congress.gov/bill/114thcongress/senate-bill/764 [https://perma.cc/QNU9-QUQ4] (last visited Mar. 27, 2017).

${ }^{253}$ See generally Right to Know Center, supra note 4.
} 
farmers are affected on a daily basis by the continuous back and forth in the biotechnology debate. American farmers grow ten different types of genetically engineered crops, and $92 \%$ of all the country's corn and soybeans derive from genetically engineered seeds. ${ }^{254}$ Consequently, farmers, who have seen a $68 \%$ lift in income by using biotechnology, ${ }^{255}$ rely on the cultivating and selling of genetically engineered crops for much of their livelihood.

The American agricultural industry faces an uncertain financial future triggered by consumer confusion regarding genetically engineered foods. In the past, corn prices saw a worldwide drop because of "consumer backlash when it was revealed that it [genetically engineered crops] had gotten into the food supply." 256 Presently, harsh criticisms of the agriculture sector's use of biotechnology and threats of mandatory labeling prolong this backlash. Antibiotechnology advocates assert that the agrichemical and food industries conceal health risks associated with genetically engineered crops and employ tactics to make these foods appear healthier. ${ }^{257}$ Monsanto, the world's largest seed company, ${ }^{258}$ holds patents on the well-known and widely used "Round-Up Ready" seeds and remains the

\footnotetext{
${ }^{254}$ Barry Petersen, Digging for Seeds of Truth in GMO Debate, CBS NEws (Jan. 17, 2016, 9:47 AM), http://www.cbsnews.com/news/digging-for-seeds-of-truth-in-gmodebate/ [https://perma.cc/3K88-FH3H].

${ }^{255}$ Examination: Hearing, supra note 1, at 90 (Response of Nina V. Fedoroff, Ph.D., Senior Science Advisor, Olsson Frank Weeda Terman Matz PC).

${ }^{256}$ Kevin O'Hanlon, StarLink Corn Settlement Also to Include Interest, USA TODAY (Aug. 23, 2004, 5:55 PM), http://usatoday30.usatoday.com/tech/news/techpolicy/business/200408-23-starlink-snafu_x.htm [https://perma.cc/RN4A-N27U].

${ }^{257}$ Gary Ruskin, Seedy Business: What Big Food is Hiding With Its Slick PR Campaign on GMOs, U.S. RIGHT TO KNOW 4, 5 (Jan. 2015), http://usrtk.org/seedybusiness.pdf [https://perma.cc/3GCD-BZE9].

${ }^{258}$ Petersen, supra note 193.
} 
chief target of many of these claims. ${ }^{259}$ Additionally, increased litigation against agricultural seed and chemical companies, like Monsanto and Syngenta, continues to propagate these negative opinions about genetically engineered crop production. ${ }^{260}$

Mandatory labeling of genetically engineered foods, along with unfavorable inferences placed on the agriculture industry, will only further cause a chilling effect for farmers of genetically engineered plants. Mandatory labeling could lower yields, decrease productivity, provide fewer seed options for planting, and have a harsher impact on the environment. ${ }^{261}$ Financially, between late 2015 through 2016 , farm income is predicted to fall $54 \%$ from its position two years before, with corn prices decreasing from $\$ 7.50$ a bushel to $\$ 3.78$ a bushel. ${ }^{262}$ When markets prices drop, farmers usually keep producing at the same level in an effort to increase production and offset the lower prices. ${ }^{263} \mathrm{But}$, the market does not "adjust to low prices with less production." 264 These damaging consequences from potential mandatory labeling threaten farmers' abilities to

\footnotetext{
259 Lessley Anderson, Why Does Everyone Hate Monsanto? MODERN FARMER (Mar. 4, 2014), http://modernfarmer.com/2014/03/monsantos-good-bad-pr-problem/ [https://perma.cc/8WLC-8YVJ].

${ }^{260}$ See, e.g., In re Syngenta AG MIR 162 Corn Litigation, Nos. MDL 2591, 14-MD-2591-JWL, 2015 WL 5607600 (D. Kan. Sept. 11, 2015).

${ }^{261}$ Examination: Hearing, supra note 1, at 40 (statement of Chris Policinski, President and Chief Exec. Officer, Land O' Lakes, Inc.).

262 Nelson D. Schwartz \& Julie Creswell, A Global Chill in Commodity Demand Hits America's Heartland, N.Y. Times (Oct. 23, 2015), http://www.nytimes.com/2015/10/25/business/energyenvironment/americas-heartland-feels-a-chill-from-collapsingcommodity-prices.html?src=me\&_r=0 [https://perma.cc/6HWX-JK8A].

263 Jon Lauck, After Deregulation: Constructing Agriculture Policy in the Age of "Freedom to Farm," 5 DRAKE J. AGRIC. L. 3, 5 (2000).

${ }^{264} \mathrm{Id}$. at 6.
} 
fully utilize biotechnology to sustainably feed an evergrowing world population. ${ }^{265}$

The world is experiencing a rising demand in agriculture crop production due to an increasing human population. ${ }^{266}$ By the year 2050, approximately nine billion people are estimated to inhabit the world. ${ }^{267}$ To meet basic demands, the amount of food production will have to rise anywhere from $60 \%$ to $110 \%{ }^{268}$ Today, however, crop yields are not increasing at a rate that will support the projected 2050 population. ${ }^{269}$ Two options exist in order to encounter this projected rate: boost crop yields or clear land for agriculturebased usage. 270

Increasing crop yields remains one of the most sustainable methods for food security, ${ }^{271}$ and the best way to accomplish that feat is through genetically engineered plants. In fact, crop yields have been shown to grow $21 \%$ when using biotechnology. ${ }^{272}$ Farmers use genetically engineered crops to increase efficiency and produce "the

265 Examination: Hearing, supra note 1, at 2 (statement of The Chairman, Hon. K. Michael Conaway, Rep. from Texas).

${ }^{266}$ Deepak K. Ray et al., Yield Trends Are Insufficient to Double Global Crop Production by 2050, 8 PLOS ONE e66428 (Jun. 2013), http://journals.plos.org/plosone/article?id=10.1371/journal.pone.00664 28 [https://perma.cc/2VVL-VWKR].

267 Global Agriculture Towards 2050, FoOD AND AGRIC. ORG. OF THE UNITED NATIONS (Oct. 2009), http://www.fao.org/fileadmin/templates/wsfs/docs/Issues_papers/HLEF 2050_Global_Agriculture.pdf [https://perma.cc/M6R8-D9MC].

${ }^{268}$ Ray et al., supra note 205.

${ }^{269} \mathrm{Id}$.

${ }^{270} I d$.

${ }^{271} I d$.

272 Wilhelm Klümper and Matin Qaim, A Meta-Analysis of the Impacts of Genetically

Modified Crops, 9 PLOS ONE el11629 (Nov. 2014), http://journals.plos.org/plosone/article?id=10.1371/journal.pone.01116 29 [https://perma.cc/4UDV-P3YA]. 
same amount of crops with only [sixty] percent of the land used in 1980." 273 Although organic farming is considered to be an acceptable solution, organic yields are not sufficient. At this time, organic yields rank $19.2 \%$ lower than those derived from conventional methods. ${ }^{274}$

Mandatory labeling will necessitate more stringent standards from food manufacturers trying to meet individual state standards. ${ }^{275}$ To allow for maximum productivity, the United States and other countries need to provide attainable structures for farmers to continue to grow crops, remain competitive in the agriculture sector, and earn a profitable income. ${ }^{276}$ The Act affords this flexible structure for farmers growing genetically engineered crops. It permits farmers to see higher yields and maintain financial stability without the threat of less productivity caused by mandatory labeling and its implications on genetically engineered crops.

\footnotetext{
${ }^{273}$ Hank Campbell, Less Consumption is Better-If It's For Someone Else, SCIENCE 2.0 (Feb. 17, 2011, 12:29 PM), http://www.science20.com/science_20/less_consumption_better_if_its_ someone_else-76445 [https://perma.cc/6FT8-NLRF].

274 Sarah Yang, Can Organic Crops Compete With Industrial Agriculture? BERKELEY NEWS (Dec. 9, 2014), http://news.berkeley.edu/2014/12/09/organic-conventional-farmingyield-gap/ [https://perma.cc/995H-W87T].

${ }^{275}$ Global Agriculture Towards 2050, supra note 206.

${ }^{276} \mathrm{Id}$.
} 


\section{SOLUTIONS}

\section{A. Consumer Education}

Consumer confusion can be more readily prevented through education. Blake Hurst, President of the Missouri Farm Bureau, stated that the biggest challenge for farmers is properly informing consumers. ${ }^{277}$ Yet, genetically engineered crops and foods are "the most extensively tested crops ever added to our food supply." 278 In fact, consumers "have been eating a GMO [genetically engineered food] for thousands of years without knowing it," 279 and have seen no adverse health effects. Genetic engineering has actually been prevalent in breeding systems for centuries to produce better crops and medicines, such as penicillin, which individuals frequently use. ${ }^{280}$ Consumers need to be made aware of the research, testing, and results of studies conducted by highly regarded organizations. Evidence from these studies

277 Benjamin Herrold, Farmers Discuss Impacts of GMO Tech, Labeling, IOWA FARMER TODAY (Jan. 22, 2015, 6:00 AM), http://www.iowafarmertoday.com/news/crop/farmers-discuss-impactsof-gmo-tech-labeling/article_21537fb2-a1a4-11e4-adbd9b301b2ed318.html [https://perma.cc/LZ6Q-C2CU].

${ }^{278}$ Van Eenennaam et al., supra note 17, at 4 (quoting the American Association for the Advancement of Science).

${ }^{279}$ Michaeleen Doucleff, Natural GMO? Sweet Potato Genetically Modified 8,000 Years Ago, NAT'L PUB. RADIO (May 5, 2015, 1:19 PM), http://www.npr.org/sections/goatsandsoda/2015/05/05/404198552/natu ral-gmo-swnt-potato-genetically-modified-8-000-years-ago [https://perma.cc/N24N-QJGB] (last updated May 5, 2015, 2:51 PM).

${ }^{280}$ Labeling of Bioengineered Foods, AM. MED. Assoc. CounCIL ON SCI. \& PUB. HEALTH, Rep. 2-A-12, 1 (2012), http://factsaboutgmos.org/sites/default/files/AMA\%20Report.pdf [https://perma.cc/8D9L-UKQD]; History of Biotechnology, BIOTECHNOLOGY INNOVATION ORG., https://www.bio.org/articles/history-biotechnology [https://perma.cc/6NFX-GNBR] (last visited Mar. 10, 2016). 
confirms that genetically engineered crops in the market provide no unique health risks and are comparable to those foods produced through traditional breeding methods. ${ }^{281}$

Additionally, many of the top health and science organizations in the nation, such as the World Health Organization, the American Medical Association, National Academy of Science, and the American Association for the Advancement of Science all reach the same conclusion: no good evidence indicates that genetically engineered crops negatively affect human health. ${ }^{282}$ Moreover, biotechnology delivers options to help improve the health of humans and crops.

\section{Genetically Engineered Foods Have Saved Crops and Humans}

Food production greatly benefits from developments in biotechnology. ${ }^{283}$ While opponents still argue against genetically engineered foods, several instances demonstrate how these foods help rescue crops from near extinction and present healthier food options for malnourished individuals.

First, two species of fruit were completely rejuvenated by biotechnology. During the early 1990s, the Hawaiian papaya crop faced extinction. ${ }^{284} \mathrm{~A}$ ringspot virus and insect infestation plagued the papaya. ${ }^{285}$ Farmers tried traditional methods of crop rotation, quarantine, and selective breeding,

281 Societal Benefits of Biotechnology: Hearing, supra note 107, at 12 (statement of Calestous Juma, Ph.D., Professor and Director, Sci., Tech., and Globalization Project, John F. Kennedy School of Government, Belfer Center for Sci. and Int'l Affairs, Harvard University).

282 Saletan, supra note 73.

${ }^{283}$ See Examination: Hearing, supra note 1, at 1-2 (statement of The Chairman, Hon. K. Michael Conaway, Rep. from Texas).

${ }^{284}$ Saletan, supra note 73.

${ }^{285} I d$. 
all to no avail. ${ }^{286}$ By utilizing biotechnology, a scientist transplanted genes from a non-harmful part of the ringspot virus into the papaya fruit's DNA. ${ }^{287}$ The successful transfer saved the entire Hawaiian papaya industry. ${ }^{288}$

Next, over a ten-year period, Florida orange groves felt serious effects from a greening disease, which attacked the orange trees' trunks and made the trees produce small, bitter oranges that did not reach full maturity. ${ }^{289}$ The disease caused the prices of Florida oranges, used to produce a majority of America's orange juice stock, to go up while the supply dwindled. ${ }^{290}$ Farmers and researchers spent millions to find a solution with little success. ${ }^{291}$ However, one Florida citrus grower obtained approval by the FDA to use greeningresistant trees implanted with protein genes from spinach, which prevents the greening bacteria from inhabiting the tree. $^{292}$

Additionally, genetically engineered foods provide nutritional options for individuals with little or no access to vital nutrients. Currently, a quarter of one billion young children, in underdeveloped countries, suffer from Vitamin A deficiency. ${ }^{293}$ Each year, this deficiency leads to the blindness of 250,000 to 500,000 children and even death. ${ }^{294}$

${ }^{286} I d$.

${ }^{287} I$ d.

${ }^{288} I d$.

289 Joe Satran, Greening-Resistant GMO Oranges Come One Step Closer to Market. Here's Why You Should Care, THE Huffington PosT (May 14, 2015, 1:46 PM), http://www.huffingtonpost.com/2015/05/14/gmo-oranges-citrusgreening-southern-gardens_n_7244858.html [https://perma.cc/8MY7H7CR] (last updated May 15, 2015, 1:59 PM).

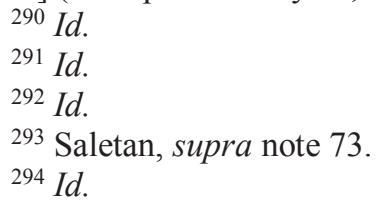


Many of those adolescents live in areas where the main food source is rice, which does not contain Vitamin A rich betacarotene. $^{295}$

To combat these devastating consequences, a genetically engineered version of rice implemented with beta-carotene, also known as "Golden Rice," was developed. ${ }^{296}$ Former President Bill Clinton praised this genetically engineered food as a tool that "could save 40,000 lives a day" in underdeveloped countries. ${ }^{297}$ Also, Tufts University issued reviews based on a clinical trial in China and found no health or safety concerns. ${ }^{298}$ The review concluded that "Golden Rice" could provide "[fifty] percent of the recommended daily intake of [V]itamin A" and afford children a chance at a healthier life. ${ }^{299}$

\section{Organic Food as an Alternative}

Consumers, who advocate for mandatory labeling, frequently reiterate the claim that they want to know what is in their food and deserve an option of choosing food not produced through genetic engineering. Yet, these individuals already possess this option and have for years: organic food.

Organic food complies with the Organic Foods Production Act, ${ }^{300}$ a strict and distinct set of standards, in

\footnotetext{
${ }^{295} I d$.

${ }^{296} \mathrm{Id}$.

${ }^{297} I d$.

${ }^{298}$ Id.; Academics Review, Tufts University Statement on Golden Rice Research (Sept. 19, 2013), http://academicsreview.org/2013/09/tufts-university-statement-ongolden-rice-research/ [https://perma.cc/L2F7-URH3].

${ }^{299}$ Academics Review, supra note 237.

3007 U.S.C. $\S 6508$ (2015).
} 
order to be certified. ${ }^{301}$ Farmers must plant organic seeds in ground that has not been subjected to any banned or synthetic substances over the past three consecutive years. ${ }^{302}$ Genetically engineered seeds and synthetic ingredients, such as some fertilizers, pesticides, or herbicides, are firmly prohibited. ${ }^{303}$ Furthermore, farmers need to show their methods of preventing the organic crops' contact with any genetically engineered plants. ${ }^{304}$ To be labeled as organic, farmers follow these production standards, use no biotechnology or forbidden substances, and the process has to be overseen by a USDA National Organic Program certifying agent. ${ }^{305}$

Because organic farming requires following stringent certification and labeling processes, consumers can confirm they are buying and eating food produced with absolutely no genetic engineering. Therefore, mandatory labeling of genetically engineered foods is not necessary. Consumers simply need to look for the USDA certified seal of " 100

301 Organic Agriculture, U.S. DEP'T OF AGRIC. (USDA), http://www.usda.gov/wps/portal/usda/usdahome?contentidonly=true\&c ontentid=organic-agriculture.html [https://perma.cc/6LLU-C3G4] (last updated Jan. 9, 2015).

302 Organic Production and Handling Standards, U.S. DEP'T OF AGRIC.

(USDA), http://www.ams.usda.gov/sites/default/files/media/Organic\%20Product ion-Handling\%20Standards.pdf [https://perma.cc/TC6D-RSEZ] (last updated Oct. 2011).

303 Can GMOs Be Used in Organic Products?, U.S. DEP'T OF AGRIC. (USDA) (May 2013), http://www.ams.usda.gov/sites/default/files/media/Can\%20GMOs\%20 be\%20Used.pdf [https://perma.cc/D6T2-HXQD]; Organic Production and Handling Standards, supra note 241.

${ }^{304}$ Can GMOs Be Used in Organic Products?, supra note 242.

${ }^{305}$ Labeling Organic Products, U.S. DEP'T OF AGRIC. (USDA) (Oct. 2012),

http://www.ams.usda.gov/sites/default/files/media/Labeling\%20Organi c\%20Products.pdf [https://perma.cc/46K5-3H5F]. 
Percent Organic" or "Organic" to guarantee they are consuming foods made with no biotechnology. ${ }^{306}$

B. The Safe and Accurate Food Labeling Act of 2015:

\section{Revisited}

The Safe and Accurate Food Labeling Act of 2015 imparts additional consumer knowledge by requiring a definition for the term "natural" and affording advocates, companies, and restaurants a chance to label their products through a voluntary labeling process. The Act begins the procedure of compelling the FDA to prepare a definition for "natural." The FDA shall propose suggested regulations, such as defining this term, within eighteen months if the bill was passed into law. ${ }^{307}$

While this time frame might seem lengthy, it is relatively short compared to the twenty years that the FDA has gone without adequately defining the term. By better completing the term "natural," litigation may greatly decrease, and consumer confidence and knowledge may increase. Furthermore, because genetically engineered foods are considered to possess no greater health risks than those foods generated through traditional breeding methods, ${ }^{308}$ genetically engineered crops should be deemed "natural" if the food as a whole is not combined or made with artificial colors or flavorings.

${ }^{306} I d$.

${ }^{307}$ Safe and Accurate Food Labeling Act of 2015, H.R. 1599, 114th Cong. § 302(a) (2015).

308 Societal Benefits of Biotechnology: Hearing, supra note 107, at 12 (statement of Calestous Juma, Ph.D., Professor and Director, Sci., Tech., and Globalization Project, John F. Kennedy School of Government, Belfer Center for Sci. and Int'l Affairs, Harvard University). 
Next, the Act establishes a voluntary labeling system through the Agriculture Marketing System of the USDA to grant producers the opportunity to label their products as non-genetically engineered on their own recognizance. ${ }^{309}$ Through this process, manufacturers can submit their product to the program, and USDA certified agents will determine if the foods contain any genetically engineered elements. ${ }^{310}$ If it contains none of these components, the agent seals the product with a label stating that it was not produced with any genetic engineering. ${ }^{311}$ Therefore, if companies choose to "position their brands" to ensure consumers will continue to buy their products, they may do so through a government mandated system. The Act would still have potential to create and prolong health halos.

Additionally, section 113 of the Act requires that any state law enacting mandatory labeling will be preempted. ${ }^{312}$ One bright note from the passage of S.764 is that this important preemption section from the Act is the only portion to be incorporated into the new federal mandatory labeling law. ${ }^{313}$ S.764 states

no State. . . may directly or indirectly establish under any authority or continue in effect as to any food. . . any requirement relating to the labeling of whether a food. . . or seed is genetically engineered. . . or was

309 Safe and Accurate Food Labeling Act of 2015, H.R. 1599, 114th Cong. § 291A (2015).

${ }^{310}$ Id. $\S 291 \mathrm{~A}(\mathrm{c})$.

${ }^{311}$ Id. $\S 291 \mathrm{~A}(\mathrm{~d})$.

${ }^{312}$ Id. $\S 113$ (2015).

313 National Bioengineered Food Disclosure Standard, Pub, L. No. 114-216, $130 \quad$ Stat. 834, 838, $\quad$ 295(b) (2016), https://www.congress.gov/114/plaws/publ216/PLAW-114pub1216.pdf [https://perma.cc/G6QQ-EXR2]. 
developed or produced using genetic engineering. . . . 314

Thus, states cannot issue laws demanding labeling of genetically engineered food entering interstate commerce, unless the language of the law is the same as S.764. ${ }^{315}$ This preemption creates uniformity throughout the country by preventing these state-by-state labeling laws, and manufacturers can confirm that their products are being regulated under one standard without having to label genetically engineered plants for one state and not another.

Kansas Congressman Mike Pompeo, the House sponsor for the Act, is pleased by the passage of S.764 and the prevention of patchwork labeling laws that "would have [had] disastrous effects on food supply chains, our agricultural communities, and American families." 316 Litigation, such as Sorrell, is now moot because state laws are preempted. This uniform system does not force farmers and manufacturers to make significant changes or face lower incomes. Hence, consumers may still obtain their products for a reasonable price while also seeing necessary protection of their Constitutional rights of citizens.

Yet, while all of these positive attributes of the Act promote positive change in the labeling debate, the Act has been put on a permanent backburner to make room for S.764. Unlike the Act, S.764, while aimed to bring a much needed compromise to both sides of the genetically engineered debate, has instead found opposition or criticism from each

314 Id.

${ }^{315} \mathrm{Id}$.

316 Press Release, U.S. Congressman Mike Pompeo, Pompeo Pleased by House Passage of Food Labeling Legislation (July 14, 2016) (http://pompeo.house.gov/news/documentsingle.aspx?DocumentID=39 9076) [https://perma.cc/37NS-CA5P]. 
side. ${ }^{317}$ Vermont Senator Bernie Sanders, a stanch supporter of his home state's former mandatory labeling legislation, claims this law does nothing to inform the consumer about the contents of their food. ${ }^{318}$

Additionally, politicians and supporters of agriculture and the Act's proposed voluntary labeling are also troubled. While in support S.764's preemption portion, ${ }^{319}$ individuals, such as Iowa Senator Chuck Grassley, want lawmakers to move away from "non-science based agenda driving law and rules" 320 and focus on science. Zippy Duvall, president of the American Farm Bureau, offers a similar view, commenting that no "documented health risks from genetically engineered food" have been shown. ${ }^{321}$ Yet, even with these concerns, the consensus among supporters of agriculture tends to be the "bill is far from perfect," but national unity in labeling through pre-emption, whether mandatory or not, is of the essence. ${ }^{322}$

However, the Act and its voluntary labeling offer a much-needed and more appeasing compromise to both sides of the debate. By implementing the Act, companies can label their products if they desire, but a uniform standard will also be in place to protect individuals from the some of the costs,

\footnotetext{
${ }^{317}$ See Lowe, supra note 100.

${ }^{318}$ Roseboro, supra note 57; see Lowe, supra note 100.

${ }^{319}$ National Bioengineered Food Disclosure Standard, Pub, L. No. 114-216, $130 \quad$ Stat. $\quad 834, \quad 838, \quad \S 295(\mathrm{~b}) \quad$ (2016), https://www.congress.gov/114/plaws/publ216/PLAW-114publ216.pdf [https://perma.cc/G6QQ-EXR2].

${ }^{320}$ Lowe, supra note 100.

${ }^{321} \mathrm{Id}$.

322 Press Release, Am. Farm Bureau, American Farm Bureau Supports National GMO Pre-emption Bill (Jun. 27, 2016) (http://ww.fb.org/newsroom/american-farm-bureau-supports-nationalgmo-pre-emption-bill) [https://perma.cc/7TJW-72CB]; see generally Press Release, U.S. Congressman Mike Pompeo, Pompeo Applauds Senate Passage of Critical Food Labeling Legislation (July 8, 2016) (http://pompeo.house.gov/news/documentsingle.aspx?DocumentID=39 9072) [https://perma.cc/5BM3-MNQR].
} 
as mentioned throughout this Note, of making labeling a mandatory action. Additionally, other sections of the Act, such as defining "natural" foods, could possibly offset the potential health halo effects by properly educating consumers in their decisions and giving them more knowledge about genetically engineered foods.

\section{CONCLuSion}

While this Note calls for a uniform federal framework for the labeling of genetically engineered foods, the passage of S.764 into federal law creates further complications in this growing biotechnology debate. Although S.764 takes a cue from the Act and prevents patchwork legislation, mandatory labeling of foods, produced through biotechnology, presents many costs that outweigh any immediate benefits. The costs to consumers, manufacturers, distributors, producers, and farmers could be staggering and could cause damaging effects on the genetically engineered crop market. A voluntarily labeling system, as provided in The Safe and Accurate Food Labeling Act of 2015, offers a stronger solution and compromise for both sides of this issue. The Act would deliver a uniform, national system to ensure that any genetically engineered crops sent into interstate commerce are healthy and safe for all.

Additionally, the Act clears up some consumer confusion by requiring the FDA to define "natural" after a twenty-year long period of indecision. While this Act benefits those who are against mandatory labeling, it also affords a strong concession for those who seek labeling as the solution. The Act sets up a voluntary labeling program with the USDA, which allows companies to label on their own accord. Yet, with the passage of S.764, mandatory labeling has become a reality. The FDA will not be required to make much needed changes, and unfortunately, the strong aspects of the Act that could prevent brand positioning and 
further consumer confusion remain unaddressed by this new federal law.

Still, no law will completely solve all of the problems associated with this issue. First, consumers need to continue educating themselves on genetically engineered crops and consider both sides of the issue to make an informed, logical choice instead of only relying on health halos created by brand positioning. Similar to voting for political leaders, consumers should read, watch, and listen to both sides of the debate to form their own opinion.

Second, as technology advances and the implementation of mandatory labeling takes effect, Congress may amend the bones of S.764 to suit the times, which could create an opening for the addition of unused aspects of the Act. Thus, legislators also need to listen to both sides, continue to monitor how the new federal law is working, conduct studies, and make adjustments accordingly.

While the Safe and Accurate Food Labeling Act of 2015 provides realistic solutions to this hotly contested topic, Americans must face a future with mandatory labeling and potential negative effectives on consumers, manufacturers, and farmers. But, as Kansas Congressman Mike Pompeo pointed out, S.764 may not be the "ideal solution," but federal legislation on labeling laws of genetically engineered foods can still accomplish objectives to "protect [Kansas] families' access to safe and affordable food and [Kansas] farmers' ability to feed a growing world," 323 a goal that extends to all Americans. The opposing sides likely will never reach a consensus, but at this time, consumers, manufacturers, and farmers should take necessary steps to ensure they are trying to meet these goals of keeping the nation and themselves informed and positively promoting and supporting the production of this nation's food supply.

${ }^{323}$ Press Release, U.S. Congressman Mike Pompeo, supra note 261. 